Artikel Review

\title{
Seksualitas Bulu Babi (Echinoidea) dan Kematangan Gonad Diadema setosum
}

\section{Lestari N. Siki ${ }^{*}$}

*Jurusan Manajemen Sumber Daya Perairan, Fakultas Perikanan dan IImu Kelautan, Universitas Negeri Gorontalo. Email: lestarinsiki@gmail.com

\section{Pendahuluan}

Secara geografis Indonesia memiliki sumberdaya laut yang sangat luas yang berpotensi untuk pemnfaatan dan sumberdaya lestari (Zakaria, 2013 dalam Indrawati dkk, 2018). Fauna Echinodermata di dunia terdapat sebanyak kurang lebih 6000 jenis dan diperkirakan 950 jenis diantaranya adalah bulu babi, yang terdiri atas 15 ordo, 46 famili dan 121 general (Suwignyo et al, 2005) dalam Musfirah, 2018). Bulu babi sering berasosiasi dengan padang lamun, di daerah lamun keberadaan bulu babi memiliki kategori tersendiri tetapi masyarakat pesisir belum mengetahui hal tersebut. Penyebaran bulu babi atau landak laut sudah hampir seluruh perairan terdapat jenisnya terutama jenis Holothuroidea (teripang) (Tanjung, 2017).

Echinodermata adalah biota laut yang hidup berkumpul kuat dengan ekosistem padang lamun, bulu babi juga merupakan biota pada siang hari mereka bersembunyi di bebatuan atau dibagian terumbu karang sedangkan pada malam hari mereka keluar dari tempat persembunyiannya dengan mencari makanan (Zakaria,2013). Tingkat pematangan gonad (TPG) merupakan tahapan yang sebelum dan sesudah dalam pemijahan bulu babi atau landak laut (Lutfiyani, 2019). Salah satu faktor yang bernilai tinggi pada gonad bulu babi berkualitas terdapat pada warnanya (Kadir, 2009 DalamTupan, J \& Bernita br Silaban, 2017).

Salah satu masalah sekarang sumber daya laut yang mengalami penurunan adalah Echinodermata yang sangat menonjol penurunannya yaitu Holothuroidea (teripang), Asteroidae 
(bintang laut), dan Echinoidae (landak laut) (Suparna, 1993 dalam, Ariyanto 2016;; Nane 2019b). Diadema sitosum merupakan salah satu jenis bulu babi yang ada di Indonesia memiliki kadar vitamin tinggi dan sangat bermanfaat bagi tubuh manusia (Pringgenies dkk, 2012). Bulu babi menyukai substrat yang agak keras, biasanya di perairan padang lamun substrat yang terdiri dengan pasir dan juga terumbu karang (Padang dkk, 2019; Nane dkk., 2020). Bagian mulut dari bulu babi terdapat salah satu membran peristome yang di dalamnya terdapat organ disebut Aristoteles lantern yang berfungsi untuk mengambil dan mengunyah makanan dari substrat sehingga bulu babi dapat mudah mencari makan (Nazar, 2017). Namun, yang disayangkan masyarakat sampai sekarang belum bisa menyadari bahwa pemanfaatan bulu babi untuk keperluan ekonomi jika berlangsung hingga jangka panjang akan menyebabkan populasi bulu babi atau landak laut menurun (Yulianto, 2010 dalam Laning dkk, 2018; Nane, 2019c; 2019d).

Bulu babi memiliki bentuk tubuh segilima, mempunyai lima pasang garis kaki tabung dan berduri yang dapat membantu biota tersebut untuk berjalan dan bergerak baik dipasir maupun di sela-sela terumbu karang (Mistiasih, 2013). Pengaruh kerusakan ekosistem terumbu karang seperti aktivitas manusia dalam pembuatan dermaga dan keramba diperairan pantai dapat mempengaruhi penurunan populasi bulu babi (Ristanto dkk, 2017). Pemanfaatan gonad bulu babi sudah lama di manfaatkan masyarakat sebagai makanan sehari-sehari seperti digoreng, dibakar, dan dikukus (Chasanah dan Andamari 1997 Dalam Silaban dkk, 2013). Diluar negeri bulu babi diperjualkan sangat mahal contohnya dinegara Italia, Cina, Hongkong dan Korea, serta mereka pasarkan bulu babi dalam keadaan segar, beku, asin, kering baik produk fermentasi maupun kalengan (Hasan, 2002).

Organisme ini memproduksi makanan racun dari diadema sitosom hanya ringan dan tidak membahayakan manusia yang mengkonsumsi (Aprilia, 2012). Diadema sitosom ini salah satu spesies bulu babi yang sering ditemukan diseluruh perairan pantai baik daerah pasang surut maupun diperairan dalam (Steven dkk, 2014). Gonad diadema sitosom terkenal mempunyai lima asam amino esensial bagi orang dewasa dan dua asam amino bagi anak- 
anak (Pringgenies dkk, 2018). Permintaan akan komunitas ini dari tahun ke tahun sangat meningkat Karena dalam pemasarannya sangat banyak keunrtungannya bagi mastarakat, sedangakan gonad bulu babi menurun permintaannya (Hmmer, 2006 Dalam Angnette dkk, 2010). Masyarakat setempat lebih mengenalnya sebagai telur bulu babi. Sebagai organ reproduksi, maka gonad merupakan pabrik benih yang dipastikan memiliki protein tinggi (Rachmawaty, 2004 Dalam Iriyanto dkk, 2016). Upaya dalam peningkatan reproduksi bulu babi mengetahui teknik dan cara bagaimana pengelolaannya, agar hasil yang didapatkan lebih tinggi dan sehingga populasi dan restikong dapat terkendali (Tasruddin \& Aonurafiq, 2016).

Pada umumya jenis D. setosom merupakan biota ynag ditemukan di daerah terumbu karang atau substrat berbatu diperairan dangkal kurang lebih 1-6 m. D. setosom ini merupakan hewan amnivora dan pemakan detritus dapat mencerna substrat berpasir (Putra dkk, 2017). Pemanfaatan gonad bulu babi di Jepang yaitu sebagai komponen utama dalam masakan shusi, masakan yang diolah khusus, dimakan mentah dengan bumbu cuka, kecap atau diasin (Afifudin dkk, 2014). Menurut Ulfana (2007) dalam Tupan dkk, 2017, ada 3 jenis yang dapat dikembangkan di Indonesia yakni dari jenis Echinometra spp, Tripneustes gratilla, dan Diadema setosum. Ketiga jenis bulu babi ini selain pertumbuhannya cepat juga mampu menghasilkan gonad yang lebih besar dibandingkan jenis bulu babi lainnya, Pematangan gonad pada bulu babi sangatlah bermanfaat bagi manusia kerena dengan harga jual yang tinggi dan nilai vitaminnya sangat tunggu juga.

Bulu babi memiliki beragam manfaat. Sebagian memiliki manfaat sebagai bahan pangan, ekologi, ekonomi dan sifat racun. Sebagian lain telah dimanfaatkan sebagai organisme model, hewan hias dan digunakan dalam bidang kesehatan terutama untuk pengobatan penyakit pada manusia, bulu babi dapat menjadi penghasilan masyarakat pesisir lebih meningkat karena apabila di indonesia sudah banyak masyarakat mengkonsumsinya maka, nilai jual beli gonad bulu babi tidak akan menurun.(Hamid A, 2010). Keberadaan bulu babi juga dapat di pengaruhi juga dengan faktor fisika kimia pada lingkungan perairan (Anwar dkk, 2015). Bulu babi memiliki fisik 
pertahanan (duri) dan yang membuat mereka cocok untuk bertahan dan melindungi diri dari organisme laut seperti moluska, udang, kepiting, polychaetes (cacing anelida), copepods (crustacea kecil), dan ikan, (Ayyagari dan Kondamudi, 2014) Dalam Anwar dkk, 2015). Bulu babi. T. gratilla digunakan sebagai organisme model dalam menentukan jenis kelamin berdasarkan kehadiran, panjang, dan bentuk papilla genital (Lawrence 1987) dalam Toha dkk, 2012. Bulu babi di padang lamun bisa hidup soliter atau hidup mengelompok, tergantung kepada jenis dan habitatnya misalnya, jenis Diadema setosum, D. antillarum, Tripneustes gratilla, T. ventricosus, Lytechinus variegatus, Temnopleurus toreumaticus dan Strongylocentrotus spp. cenderung hidup mengelompok, sedangkan jenis Mespilia globulus, Toxopneustes pileolus, Pseudoboletia maculata, dan Echinothric diadema cenderung hidup menyendiri (Aziz, 1994) DalamLubis, 2016).

Pemanfaatan bulu babi (Echinoidea) di Indonesia kebanyakan masih dimanfaatkan untuk konsumsi harian rumah tangga yakni dengan cara menangkap langsung di habitatnya tanpa ada usaha komersialisasi dan budidaya, dan apabila bulu babi ini menurun populasinya maka masyarakat akan kehilangan pekerjaannya dan bahan makanan yang mereka konsumsi terutama masyarakat pesisir (Indra, 2007) Dalam Arhas dkk, 2015. Bulu babi atau landak laut oleh masyarakat yang tinggal di daerah pesisir pantai Kawasan Timur Indonesia lebih dikenal dengan nama "duri babi" yang merupakan salah satu dari sekian jenis makrobenthos dari kelas echinoidea yang dapat mencapai ukuran diameter cangkang $163 \mathrm{~mm}$ dan mencapai berat 200 gr. Para nelayan telah lama memanfaatkan hewan laut ini untuk diambil gonad sebagai konsumsi lokal baik mentah (segar) maupun hasil olahan, Untuk mengantisipasi kepunahan biota tersebut maka paling tepat adalah dengan melalui usaha budidaya. Selain tujum restocking di alam namum tak kalah pentingnya adalah agar dapat memenuhi permintaan gonad di pasaran internasional (Radjab, 2009).

Karakteristik bulu babi yang dikenal banyaka masyarakat banyak jenisnya terutama jenis teripang dan masi banyak lagi, serta dalam pematangan gonak bulu babi itu sendiri dapat 
bernilai ekonomis sebagai pengahasilan masyarakat pesisir Gonad bulu babi juga dapat digunakan sebagai bahan fortifi kasi pada olahan pangan karena itu pengetahuan tentang kandungan nutrisi setiap spesies bulu babi Gonad bulu babi dapat dijadikan sebagai sumber pangan alternatif karena mengandung 28 macam asam amino, vitamin B kompleks, vitamin A, mineral, asam lemak omega-3, dan omega-6. Sementara cangkangnya memiliki potensi sebagai antikanker, antitumor dan antimikroba (Aprillia, Pringgenies, \& Yudiati, 2012) dalam Hadinoto dkk, 2017). Pengambilan bulu babi atau landak laut secara berlebihan akan mengalami gangguan eskosistem perairan, sehingga landak laut akan cepat punah populasinya diadema setosum adalah salah satu jenis bulu babi yang mempunyai nilai ekonomis bagian tubuh yang dikonsumsi adalah gonad atau telurnya dan juga bagian ini pada jenis landak laut tersebut sangatlah tinggi nilai gizinya serta Cangkang bulu babi memiliki kandungan senyawa aktif yang bersifat toksik (Angka \& Suhartono, 2000) dalam Sugeng dkk, 2016.

Populasinya akan terganggu pada suhu dibawah 10 o C. Suhu tersebut sangat mempengaruhi silkus reproduksi secara manual umumnya di perairan dalam pemanfaatan gonad atau telur jenis bulu babi diadema sitosum sangatlah bermanfaat perekonomian masyarakat jika, masyarakat tidak melebihi batas dalam penangkapannya maka populasi bulu babi jenis ini akan selalu berkembangbiak (Menurut Vaitilingon et al. (2005) Dalam Nasrullah dkk, 2018). Dalam seksualitas bulu babi jenis diadema setosom sangatlah banyak manfaatnya bagi masyarakat pesisir karena dengan nilai gizi, nilai jual belinya sangat mahal, termasuk gonadnya atau dari telurnya sangatlah mahal jika diperjualkan, Masalah biologi reproduksi bulu babi perlu dikaji sebagai data awal dalam usaha pembenihan. Aspek reproduksi seperti Indeks Kematangan Gonad(IKG) secara lokal perlu diketahui karena IKG bulubabi bervariasi dari suatutempat ke tempat lainnya, siklus reproduksi bulubabi dipengaruhi oleh musim dan kondisi geografis (Siikavuopio et al., 2006) Dalam Nasrullah dkk, 2018. Oleh karena itu, kajian mengenai keberadaan bulu babi perlu dilakukan khususnya mengenai komposisi jenis bulu babi diadema setosom ini. 


\section{Kesimpulan}

Dalam pembahasan singkat diatas bahwa seksualitas bulu babi jenis (diadema sitosom) dapat disimpulkan bahwa gonad atau telur dari jenis bulu babi tersebut biasa tinggal diperairan yang bersubstrat agak berpasir yang paling dominan itu berasosiasi di padang lamun untuk mencari makanan. Bulu babi juga jenis ini banyak manfaatnya kerena memiliki nilai gizi asam amino terhadap orang dewasa dan untuk anak-anak. Bulu babi merupakan biota laut yang pada siang hari bersembunyi di bebatuan sedangkan pada malam hari mereka keluar untuk mencari makanan. Bulu babi sudah terkenal di Negar-Negara asing contohnya di Italia, Hongkong, Cina, dan Korea. Mereka mengkonsumsi makanan ini biasanya di buat shusy. Ada keunikan lagi yang didapat mengenai bulu babi ini yaitu mereka juga selain dikenal sebagai biota mematikan ternyata bulu babi memiliki nilai ekonomi yang tinggi, di pasaran bulu babi atau landak laut ini di jual dengan harga tinggi tetapi mereka menjualnya hanya gonadnya atau telur dari bulu babi tersebut. Suhu adalah satu dari beberapa faktor paling penting yang mempengaruhi pertumbuhan bulu babi suhu adalah faktor lingkungan utama yang mengendalikan fisiologi, fenologi, durasi larva planktonik dan biogeografi invertebrata laut. Suhu perairan dapat mempengaruhi proses metabolisme dan siklus reproduksi bulu babi. Suhu sangat berpengaruh terhadap perkembangan singkat periode planktonik bulu babi yang mengakibatkan penurunan tekanan predasi dan juga mengubah hubungan antar populasi. 


\section{Referensi}

Afifudin, K, I. Suseno, H. M. Jacoeb, C. 2014. Profil Asam Lemak Dan Asam Amino Gonad Bulu Babi Fatty Acid And Amino Acid Profile Of Sea Urchins Gonads. JurnalJPHPI. Departemen Teknologi Hasil Perairan, Fakultas Perikanan dan IImu Kelautan. Institut Pertanian Bogor.

Agnette, T. Junior, Zairin, M. Supriyadi, A, M. Yulianda, F. 2010. Perkembangan Gonad Bulu Babi, Tripneutes gratilla, yang Ditangkap di Perairan Teluk Kupang. Jurnal. Jurusan Perikanan dan Kelautan, Universitas Nusa Cendana, Kupang.

Anwar, C. Muzahar. Karlina, I. 2015. Bioekologi Bulu Babi (Echinoidea) di Perairan Laut Teluk Dalam Desa Malang Rapat Kecamatan Gunung Kijang Kabupaten Bintan. Jurnal Kelautan. Jurusan IImu Kelautan Fakultas IImu Kelautan danPerikanan, Universitas Maritim Raja Ali Haji.

Aprillia, A, H. Pringgenies, D. Yudiati, E. 2012. Uji Tosisitas Ekstra Kloroform Cangkang dan Duri Landak Laut (Diasema setosom) Terhadap Mortalitas Neuplius Artemia sp. Jurnal Of Marine Research. Program Studi IImu Kelautan. Fakultas Perikanan dan IImu Kelautan. Universitas Diponegoro Kampus.

Arhas, R, F. Mahdi, N. Kamal, S. 2015. Struktur Komunitas Dan Karakteristik Bulu Babi (Echinoidea) Di Zona Sublitoral Perairan Iboh Kecamatan Sukakarya Kota Sabang. Jurnal Prosiding Seminar Nasional Biotik. Program Studi Pendidikan Biologi Fakultas Tarbiyah dan Keguruan UIN Ar-Raniry.

Ariyanto, P, T. 2016. Keanekaragaman Dan Kelimpahan Echinodermata Di Pulau Barrang Lompo Kecamatan Ujung Tanah Kota Makassar. Skripsi. Fakultas Sains Dan Teknologi Uin Alauddin Makassar.

Hadinoto, S. Sukaryono, D, I. Siahay, Y. 2017. Kandungan Gizi Gonad Dan Aktivitas Antibakteri Ekstrak Cangkang Bulu Babi (Diadema Setosum). Jurnal Akuakultur.Program Studi IImu Kelautan. 
Hamid A. Abdul, Toha. 2010. Manfaat Bulu Babi (Echinoidea), Dari Sumber Pangan Sampai Organisme Hias. Jurnal Perikanan. Universitas Riau. Fakultas Perikanan dan IImu Kelautan.

Hasan, Fetrawati. 2002. Pengaruh Konsentrasi Garam Terhadap Mutu Produk Fermentasi Gonad Bulu Babi Jenis tripneustes gratilla (L). Skripsi. Progaram Studi Teknologi Hasil Perikanan. Fakultas Perikanan dan IImu Kelautan.

Indrawati, I. Hidayat, R, T. Rossiana, N. 2018. Aktivitas Antibakteri Dari Bulu Babi (Diadema Setosum) Terhadap Escherichia Coli Dan Staphylococcus Aureus. Jurnal Biodjati. Departemen Biologi Fakultas Matematika Dan IImu Pengetahuan Alam Universitas Padjadjaran. 3 (2) 2018.

Irianto, A. Jahidin. Sudarajat, W, H. 2016. Kelimpahan Bulu Babi (Echinoidea) Di Intertidal Perairan Pulau Liwutongkidi Kecamatan Siompu Kabupaten Buton Selatan. Jurnal AMPIBI. Mahasiswa Jurusan Pendidikan Biologi FKIP UHO. 1(2) hal. (27- 30) Agustus 2016.

Irvan Tanjung. 2017. ANALISIS Komponen Bioaktif Dan Antioksidan Dari Bulu Babi (Diadema Savignyi) Secara In Vitro Di Perairan Pulau Bintan Trikora Tiga Kepulauan Riau. Skripsi. Program Studi Teknologi Hasil Perikanan Fakultas IImu Kelautan Dan Perikanan Universitas Maritim Raja Ali Haji Tanjungpinang.

Laning, H, T. Yusup, S, D. Wiryatno, J. 2018. Sebaran Bulu Babi (Echinoidea) Di Kawasan Padang Lamun Pantai Merta Segara, Sanur-Bali. Jurnal Biologi. Jurusan Biologi F.MIPA Universitas Udayana, Bukit Jimbaran - Bali. 18 (2):41 - 45.

Lubis, A, S. Purnama, A, A. Yolanda, R. 2016. Spesies Bulu Babi (Echinoidea) Di Perairan Pulau Panjang Kabupaten Bangka Tengah Provinsi Bangka Belitung. Jurnal Perikanan. Program Studi Pendidikan Biologi Fakultas Keguruan dan Ilmu Pendidikan, Universitas Pasir Pengaraian. 
Lutfiyani, E. 2019. Tingkat Kematangan Gonad Bulu Babi (Diadema Setosum) Di Perairan Pulau Panjang Jepara. Skripsi. Program Studi IImu Kelautan Fakultas Perikanan Dan IImu Kelautan Universitas Diponegoro.

Mistiasih, D, W. 2013. Struktur Dan Sebaran Komunitas Bulu Babi (Echinoidea) Di Habitat Lamun Pulau Sapudi, Kabupaten Sumenep, Madura. Skripsi. Departemen IImu Dan Teknologi Kelautan Fakultas Perikanan Dan IImu Kelautan Institut Pertanian Bogor Bogor.

Musfirah. 2018. Struktur Komunitas Bulu Babi (Echinoidea) Yang Berasosiasi Dengan Ekosistem Lamun Di Pulau Barrang Lompo, Sulawesi Selatan. Skripsi. Jurusan Perikanan. Fakultas IImu Kelautan Dan Perikanan Universitas Hasanuddin Makassar.

Nasrullah, R. Sari, W. Mellisa, S. 2018. Tingkat Kematangan Gonad Bulu Babi (Tripneustes Gratilla) di Pantai Ahmad Rhangmayang Kecamatan Mesjid

Raya Kabupaten Aceh Besar. Jurnal IImiah Mahasiswa Kelautan dan Perikanan Unsyiah. Program Studi Biologi, FMIPA, Universitas Syiah Kuala, Banda Aceh. Volume 3, Nomor 1: 23-32.

Nane, L. (2019a). Efisiensi Mesin Teknologi Sapurata Dalam Mengoptimalisasi Produksi Inovasi Pangan Kukure Di Pulau Barrang Lompo, Makassar. https://doi.org/10.31230/osf.io/q8spg

Nane, L. (2019b). Impact of overfishing on density and test-diameter size of the sea urchin Tripneustes gratilla at Wakatobi Archipelago, south-eastern Sulawesi, Indonesia. BioRxiv, 727271. https://www.biorxiv.org/content/10.1101/727271v1

Nane, L. (2019c). Sea Urchin Sustainability Studies Based on Dimension Biology, Ecology and Technology at Around of Tolandono Island and Sawa Island at Wakatobi Conservation Area. https://doi.org/10.31230/osf.io/4whz6 
Nane, L. (2019d). Studi Keberlanjutan Perikanan Landak Laut Berdasarkan Dimensi Biologi, Ekologi Dan Teknologi Di Sekitar Pulau Tolandono Dan Pulausawa Kawasan Konservasiwakatobi [Skripsi, Universitas Hasanuddin]. Https://Marxiv.Org/9zdvr/

Nane, L., Baruadi, A. S. R., \& Mardin, H. (2020). The density of the blue-black urchin Echinotrix diadema (Linnaeus, 1758) in TominiBay, Indonesia. Tomini Journal of Aquatic Science, 1(1), 16-21. https://doi.org/10.37905/tjas.v1i1.5939

Nazar, M. 2017. Pola Distribusi Urchin (Echinoidea) Pada Ekosistem Terumbu Karang (Coral Reefs) Di Perairan Iboih Kecamatan Sukakarya Kota Sabang Sebagai Penunjang Praktikum Ekologi Hewan. Skripsi. Fakultas Tarbiyah Dan Keguruan Universitas Islam Negeri ArRaniry Darussalam-Banda Aceh.

Padang, A. Nurlina. Tahir Tuasikal. Subiyanto, R. 2019. Kandungan Gizi Bulu Babi (Echinoidea) (Nutrient Contains in Sea Urchin (Echinoidea). Jurnal AgribisnisPerikanan. niversitas Darussalam Ambon.

Pringgenies, D. Yoram, W. Rdho, A. 2018. Perilaku Seksual dan Kadar Testosteron Darah Tikus Putih (Rattus Norvegicus) Strain Wistar Akibat Pemberian Pakan Gonad Bulu Babi (DademaSitosom). Jurnal.Universitas Bogor.

Putra, S, N. Sari, W. Muhammadar. 2017. Studi Kematangan Gonad Bulu Babi Di Kawasan Pantai Kecamatan Mesjid Raya, Kabupaten Aceh Besar. Jurnal IImiah Mahasiswa Kelautan dan Perikanan Unsyiah. Program Studi Imu Kelautan, FKP, Universitas Syiah Kuala, Banda Aceh. Volume 2, Nomor 4.

Radjab, W, A. 2009. Reproduksi Dan Siklus Bulu Babi (Echinoidea). Jurnal. Fakultas Perikanan dan IImu Kelautan.

Ristanto, A. Yanti, H, A. Setyawati, R, T. 2017. Komposisi Jenis Bulu Babi (Kelas: Echinoidea) Di Daerah Intertidal Pulau Lemukutan Kabupaten Bengkayang. Jurnal Protobiont. Program Studi Biologi, Fakultas MIPA, Universitas Tanjungpura. Vol. 6 (1) : 59-63. 
Silaban, B, B. \& Srimariana, S, E. 2013. Kandungan Nutrisi Dan Pemanfaatan Gonad Bulu Babi (Echinothrixs Calamaris) Dalam Pembuatan Kue Bluder. Jurnal JPHPI. Jurusan Teknologi Hasil Perikanan Fakultas Perikanan dan IImu Kelautan, Universitas Pattimura - Ambon. Volume 16 Nomor 2.

Stevan, N. Syafruddin. Thamrin. 2014. Density And Distribution Pattern Of Sea Urchin Population (Diadema Setosum) On Coral Reef (Reef Flat) At Setan Island. Jurnal.Fakultas Perikanan dan IImu Kelautan.

Sugeng, H. Sukaryono, D, I. Siahay, Y. 2016. Kandungan Gizi Bulu Babi (Diadema Setosum) Dan Potensi Cangkangnya Sebagai Antibakteri. Jurnal Biologi. Pascasarjana Universitas Pattimura Program Studi IImu Kelautan.

Tasruddin, \& Aonurafiq. 2016. Perbandingan aspek ekologi dan karakteristik bulu babi Tripneustes gratilla pada lokasi berbeda. JurnalAkuakulturlndonesia. Fakultas Perikanan, Universitas Muhammadiyah Luwuk.

Toha, A, H. Pramana, A. B. Sumitr, S. Hakim, L. Widodo. 2012. Penentuan Jenis Kelamin Bulu Babi Tripneustes Gratilla Secara Morfolog.Jurnal Perikanan. Jurusan Perikanan, Fakultas Peternakan, Perikanan dan IImu Kelautan, Universitas Negeri Papua, Manokwari, Papua Barat, 2Jurusan Biologi, FMIPA Universitas Brawijaya.

Tupan, J \& Bernita br Silaban, 2017. Karakteristik Fisik-Kimia Bulu Babi Diadema Setosum Dari Beberapa Perairan Pulau Ambon. Jurnal Triton. Jurusan Teknologi Hasil Perikanan Fakultas Perikanan dan IImu Kelautan Universitas Pattimura. Volume 13, Nomor 2, Oktober 2017, hal. $71-7871$.

Zakaria, IJ. 2013. Komunitas Bulu Babi (Echinoidea) di Pulau Cingkuk, Pulau Sikuai dan Pulau Setan Sumatra Batar. Skripsi. Prosiding Semirata FMIPA. Universitas Lampung. Lampung. 